\title{
Spermatogenesis in the grey squirrel (Sciurus carolinensis) and changes during sexual regression
}

\author{
A. J. Tait* and Elizabeth Johnson \\ Zoology Department, The University, Whiteknights, Reading, RG6 2AJ, U.K.
}

\begin{abstract}
Summary. In the testes of sexually active grey squirrels 8 stages of spermatogenesis were recognized each with a characteristic association of germ cells. The low numbers of spermatozoa in squirrel testes are the result of fewer spermatogonial divisions compared with those of most other mammals as well as a low efficiency of spermatogenesis, with only $42 \%$ of the germ cells becoming spermatozoa. A period of testicular regression which may be prolonged follows the breeding season in June/July. In fully regressed testes no stages of spermatogenesis could be recognized, the lumen of the seminiferous tubules was occluded and no stages later than primary spermatocytes were seen.
\end{abstract}

\section{Introduction}

The American grey squirrel (Sciurus carolinensis) was introduced into Britain in the late nineteenth century. It has since become widespread throughout most of England and Wales and is regarded as a serious economic pest because of its habit of bark stripping young hardwood trees. In the United States and in Britain there are two peaks of litter production per annum, the first in March/April (spring) and the second in June/July (summer). Although it is agreed that adult male grey squirrels undergo periods of testicular regression, there is disagreement as to whether the regression is synchronous throughout the population (Kirkpatrick \& Hoffman, 1960; Brauer \& Dusing, 1961; Dubock, 1979b), or occurs irregularly amongst individuals so that there is no period when the whole population has regressed testes (Allanson, 1933; Pudney, 1976). When synchronous sexual cycles have been described testicular regression usually occurs in July/August and is short lived because the males mate in December/January for production of spring litters. Occasionally the testes will fail to develop for long periods after the autumn regression, with a consequent failure of spring breeding. Such a failure of spring breeding has been reported in the United States (Brown \& Yeager, 1945; Smith \& Barkalow, 1967; Nixon \& McClain, 1975) and Britain (Shorten, 1954; Taylor, 1969; Dubock, 1979b).

In previous studies the gross changes in the testes have been described and the presence or absence of spermatozoa noted. In testes of sexually active males the seminiferous tubules are wide and the tunica albuginea is thin, whereas regressed testes have narrow seminiferous tubules and a thick tunica. In the present study the changing cell associations during the stages of spermatogenesis in sexually mature testes have been described, as well as the changes occurring during testicular regression. U.K.

* Present address: Glaxo Operations U.K. Limited, Breakspear Road South, Harefield, Uxbridge UB9 6LS, 


\section{Materials and Methods}

Grey squirrels were trapped alive in Legg multicatch traps in an area of forest managed by the Forestry Commission in Southern England (National Grid Ref. SU 806 416). The forelimbs were X-rayed and male squirrels were classed as adult if the epiphyses of the wrist were fused and subsequent dried eye-lens weights indicated that they were over 12 months of age (Dubock, 1979a). Ten adult squirrels trapped in May with large scrotal testes were selected for investigation of the stages of spermatogenesis. Animals were killed with carbon dioxide and the whole animal immediately perfused via the heart. The blood was replaced with isotonic saline $(9 \mathrm{~g} \mathrm{NaCl} / 1)$ at $37^{\circ} \mathrm{C}$, followed by formal-saline at $37^{\circ} \mathrm{C}$ from a gravity feed reservoir at $150 \mathrm{~cm}$ (Glauert, 1975). The testes, prostate and seminal vesicle glands were removed and weighed. Testes were embedded in Paraplast (Sherwood Medical Ltd) sectioned at $5 \mu \mathrm{m}$ and stained in Erhlich's haematoxylin and alcoholic eosin.

To establish the frequency of each stage of spermatogenesis 50 seminiferous tubules were classified at each of 2 locations at least $500 \mu \mathrm{m}$ apart for each testis; germ cells were identified by the criteria established for the ram and the bull (Ortavant, Courot \& Hochereau, 1969) and the vole (Grocock \& Clarke, 1975). The different cell types were counted in 4 cross-sections of seminiferous tubules representative of each of the stages of spermatogenesis. Cell counts were converted to true counts using an adaptation of Abercrombie's formula (Swierstra \& Foote, 1963; Grocock \& Clarke, 1975):

$$
P=C \cdot \frac{T}{L+T} \cdot \frac{D^{\prime}}{D}
$$

where $P=$ the true number of nuclei per cross-section; $C=$ crude count of the number of whole and cut nuclei per cross-section; $T=$ section thickness in $\mu \mathrm{m} ; L=$ diameter of the nuclei in $\mu \mathrm{m}$; $D=$ diameter in $\mu \mathrm{m}$ of each particular seminiferous tubule; $D^{\prime}=$ mean diameter of seminiferous tubules.

Testes were also removed and weighed fresh from 16 other adult male squirrels killed during the breeding season. These were fixed in alcoholic Bouin, embedded, sectioned and stained as before. During a period of prolonged sexual regression between June 1977 and March 197846 male squirrels were trapped and used to examine the testicular changes at this time.

\section{Results}

Weights of testes and accessory reproductive organs are given in Table 1 .

Table 1. Mean \pm s.e.m. weights of testes, seminal vesicle and prostate glands of adult male squirrels

\begin{tabular}{lcccc}
\hline $\begin{array}{c}\text { Reproductive } \\
\text { status }\end{array}$ & $\begin{array}{c}\text { No. of } \\
\text { squirrels }\end{array}$ & Paired testes $(\mathrm{g})$ & Seminal vesicles $(\mathrm{mg})$ & Prostate (g) \\
\hline $\begin{array}{c}\text { Sexually active } \\
\text { Fixed weights }\end{array}$ & 10 & $5 \cdot 67 \pm 0.18$ & $73 \cdot 2 \pm 8.6$ & $1 \cdot 11 \pm 0 \cdot 11$ \\
$\quad$ Fresh weights & 16 & $5 \cdot 13 \pm 0.26$ & $82.6 \pm 11.0$ & $1.29 \pm 0.11$ \\
$\begin{array}{c}\text { Sexually regressed } \\
\text { Fresh weights }\end{array}$ & 46 & $0.98 \pm 0.08$ & $37.3 \pm 4.3$ & $0.31 \pm 0.03$ \\
\hline
\end{tabular}


Spermatogenesis in testes of sexually active squirrels

Eight stages of spermatogenesis were recognized (PI. 1, Figs 1-8). Table 2 shows the percentage frequencies of the spermatogenic stages: Stage VIII was the most frequent whilst Stage $V$ had the lowest frequency.

Table 2. Mean \pm s.e.m. frequencies of the stages of spermatogenesis in grey squirrels

\begin{tabular}{ccccccccc}
\hline $\begin{array}{c}\text { Spermatogenic } \\
\text { stage }\end{array}$ & I & II & III & IV & V & VI & VII & VIII \\
\hline$\%$ Frequency & $10 \cdot 1 \pm 1 \cdot 1$ & $10.5 \pm 0.6$ & $7.9 \pm 0.8$ & $10.4 \pm 0.9$ & $6.7 \pm 0.7$ & $10.4 \pm 0.5$ & $14.7 \pm 1.3$ & $29.3 \pm 1.0$ \\
\hline
\end{tabular}

Stage I. Type A spermatogonia were identified together with early leptotene and pachytene primary spermatocytes. Spermatids with round nuclei were present but there was none with an elongating nucleus.

Stage II. The characteristic feature of this stage is the elongation of the spermatid nuclei. Type A spermatogonia together with leptotene and pachytene primary spermatocytes were also present.

Stage III. All the spermatids had elongated nuclei. Intermediate and type A spermatogonia were identified together with primary spermatocytes in leptotene, zygotene and pachytene.

Stage $I V$. Spermatogonia (type A and intermediate) and primary spermatocytes in zygotene and pachytene were present. Some of the secondary spermatocytes showed evidence of the second maturation division. A few round spermatids were seen but elongated spermatids were associated in bundles.

Stage $V$. Type A and intermediate spermatogonia were present, together with primary spermatocytes in zygotene. Round spermatids and bundles of elongated spermatids were seen. A characteristic feature of this stage was the position of the Sertoli cell nuclei which were located some distance from the basement membrane towards the spermatid bundles.

Stage VI. The Sertoli cell nuclei had returned to their original position on the basement membrane. Type A and intermediate spermatogonia, early pachytene primary spermatocytes, round spermatids and bundles of elongated spermatids were all present.

Stage VII. The elongated spermatids were no longer in tight bundles and had moved towards the lumen. Type A, intermediate and type B spermatogonia were present, together with pachytene primary spermatocytes and round spermatids.

Stage VIII. Mature spermatozoa were seen lining the lumen. Spermatogonia (types A and B) were present, with primary spermatocytes in preleptotene and pachytene as well as round spermatids.

\section{Cell counts}

The numbers of each cell type at the different stages are shown in Table 3. Intermediate spermatogonia were first identified in Stage III and had doubled their number by Stage VI. Type B spermatogonia were first identified in Stage VII, and reached a maximum number by Stage VIII. Primary spermatocytes were classified as 'young' if in preleptotene, leptotene or zygotene and 'old' if in pachytene: young primary spermatocytes were first observed in Stage VIII and reached maximum numbers by Stage I of the following cycle, maturing to 'old' primaries by Stage VI and dividing to form secondary spermatocytes in Stage IV of the following cycle. The number of secondary spermatocytes counted in this stage is probably an underestimate because division to round spermatids proceeded immediately. The numbers of Sertoli cell nuclei counted at each stage remained constant. 
Table 3. Numbers of cell types at each of the eight stages of spermatogenesis in the squirrel

\begin{tabular}{|c|c|c|c|c|c|c|c|c|}
\hline & \multicolumn{8}{|c|}{ Stages of spermatogenesis } \\
\hline & I & II & III & IV & v & VI & VII & VIII \\
\hline Type A spermatogonia & $\begin{array}{l}2.8 \pm \\
0.2\end{array}$ & $\begin{array}{l}3.1 \pm \\
0.2\end{array}$ & $\begin{array}{l}3 \cdot 3 \pm \\
0.2\end{array}$ & $\begin{array}{l}2.9 \pm \\
0.2\end{array}$ & $\begin{array}{l}2 \cdot 0 \pm \\
0.2\end{array}$ & $\begin{array}{l}3.3 \pm \\
0.3\end{array}$ & $\begin{array}{l}2.7 \pm \\
0.2\end{array}$ & $\begin{array}{l}3 \cdot 0 \pm \\
0.2\end{array}$ \\
\hline Intermediate type spermatogonia & 0 & 0 & $\begin{array}{l}1.9 \pm \\
0.3\end{array}$ & $\begin{array}{l}2.4 \pm \\
0.2\end{array}$ & $\begin{array}{l}3 \cdot 1 \pm \\
0.2\end{array}$ & $\begin{array}{l}3.7 \pm \\
0.3\end{array}$ & $\begin{array}{l}3 \cdot 0 \pm \\
0.3\end{array}$ & 0 \\
\hline Type B spermatogonia & 0 & 0 & 0 & 0 & 0 & 0 & $\begin{array}{l}0.4 \pm \\
0.1\end{array}$ & $\begin{array}{l}5.2 \pm \\
0.5\end{array}$ \\
\hline 'Young' primary spermatocytes & $\begin{array}{l}9.6 \pm \\
0.3\end{array}$ & $\begin{array}{l}9.5 \pm \\
0.4\end{array}$ & $\begin{array}{l}9.1 \pm \\
0.4\end{array}$ & $\begin{array}{l}9.5 \pm \\
0.3\end{array}$ & $\begin{array}{l}8 \cdot 3 \pm \\
0.3\end{array}$ & 0 & 0 & $\begin{array}{l}3.0 \pm \\
0.5\end{array}$ \\
\hline 'Old' primary spermatocytes & $\begin{array}{l}9.3 \pm \\
0.4\end{array}$ & $\begin{array}{l}9.9 \pm \\
0.3\end{array}$ & $\begin{array}{l}9.6 \pm \\
0.3\end{array}$ & $\begin{array}{l}1.6 \pm \\
0.6\end{array}$ & 0 & $\begin{array}{l}9.1 \pm \\
0.4\end{array}$ & $\begin{array}{l}9.4 \pm \\
0.4\end{array}$ & $\begin{array}{l}9.2 \pm \\
0.4\end{array}$ \\
\hline Secondary spermatocytes & 0 & 0 & 0 & $\begin{array}{l}6.8 \pm \\
1.8\end{array}$ & 0 & 0 & 0 & 0 \\
\hline Round spermatids & $\begin{array}{c}25.5 \pm \\
0.7\end{array}$ & $\begin{array}{c}25.9 \pm \\
1.2^{*}\end{array}$ & 0 & $\begin{array}{c}12.7 \pm \\
4.0\end{array}$ & $\begin{array}{c}28.4 \pm \\
0.9\end{array}$ & $\begin{array}{c}28.3 \pm \\
0.8\end{array}$ & $\begin{array}{c}26.2 \pm \\
0.7\end{array}$ & $\begin{array}{c}25.4 \pm \\
0.8\end{array}$ \\
\hline Elongated spermatids + spermatozoa & 0 & 0 & $\begin{array}{c}28.3 \pm \\
1.3\end{array}$ & $\begin{array}{c}29.9 \pm \\
1.9\end{array}$ & $\begin{array}{c}26 \cdot 5 \pm \\
1.1\end{array}$ & $\begin{array}{c}26.7 \pm \\
1.9\end{array}$ & $\begin{array}{c}25 \cdot 0 \pm \\
1.2\end{array}$ & $\begin{array}{c}20.2 \pm \\
1.3\end{array}$ \\
\hline Sertoli cell & $\begin{array}{l}5 \cdot 3 \pm \\
0.4\end{array}$ & $\begin{array}{l}5.9 \pm \\
0.3\end{array}$ & $\begin{array}{l}5.2 \pm \\
0.3\end{array}$ & $\begin{array}{l}5.7 \pm \\
0.4\end{array}$ & $\begin{array}{l}5.9 \pm \\
0.4\end{array}$ & $\begin{array}{l}5.0 \pm \\
0.3\end{array}$ & $\begin{array}{l}5 \cdot 2 \pm \\
0.3\end{array}$ & $\begin{array}{l}5 \cdot 2 \pm \\
0.3\end{array}$ \\
\hline
\end{tabular}

Values are mean \pm s.e.m./tubule cross-section.

* Elongating spermatids.

\section{Changes in spermatogenesis during regression}

From mid-June 1977 adult male squirrels with regressing testes were trapped. From the end of June until March 1978 all of the 43 adult male squirrels trapped in the study area had testes weighing less than $2 \mathrm{~g}$, in which no stages of spermatogenesis could be recognized and the lumina of the seminiferous tubules were filled with degenerating germ cells (Pl. 1, Fig. 9). The numbers of each cell type recognized in the tubules of 20 such regressed testes (means \pm s.e.m.) were: type A spermatogonia $3.1 \pm 0.3$; intermediate type spermatogonia $0.6 \pm 0.3$; degenerating primary spermatocytes $3 \cdot 2 \pm 0 \cdot 3$; Sertoli cells $6 \cdot 2 \pm 0 \cdot 2$. Adult male squirrels trapped during March 1978 had enlarging testes in which the most advanced cell type in the seminiferous tubules was round spermatids. As assessed by testes weights, a similar prolonged testicular regression was observed in all squirrels trapped between July 1979 and March 1980. In other years, such as 1980 , testicular regression occurred throughout the population between July and November.

\section{Discussion}

The 8 spermatogenic stages recognized in this study of the grey squirrel corresponded in general terms to those described for the rat (Roosen-Runge \& Giesel, 1950), ram (Ortavant, 1958),

\section{PLATE I}

Figs 1-8. Stages I-VIII respectively of the spermatogenic cycle in testes of sexually active grey squirrels: A, type A spermatogonium; B, type B spermatogonium: I, Intermediate type spermatogonium; $\mathrm{P}$, pachytene primary spermatocyte; L, leptotene primary spermatocyte; $\mathrm{Z}$, zygotene primary spermatocyte; Sc, secondary spermatocyte; $M$, meiotic figure; $R$, round spermatid; S, Sertoli cell.

Fig. 9. Seminiferous tubules from a regressed testis showing the occluded lumen and degenerating germ cells. 


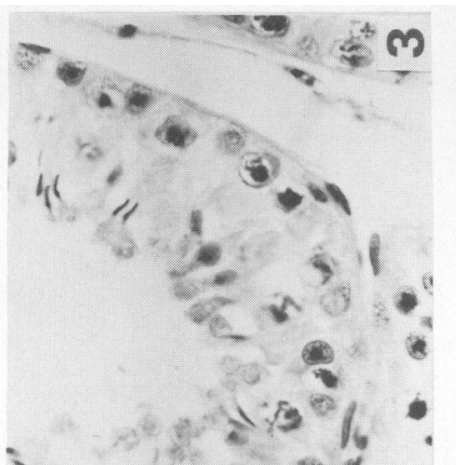

"⿻ 8

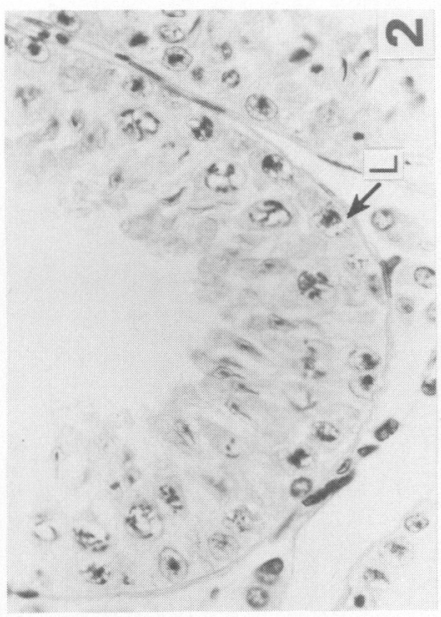

$\because \frac{1}{10}-$

$$
\begin{aligned}
& 40+3 x^{2} \\
& 7 x^{4} \times \\
& \text { (3) } 3 \text { :" } \\
& \cos ^{2}\left(7^{2}\right) \\
& \text { क क क क } \\
& \text { - }+40^{\circ} \text {. } \\
& \text { - } \rightarrow=0
\end{aligned}
$$
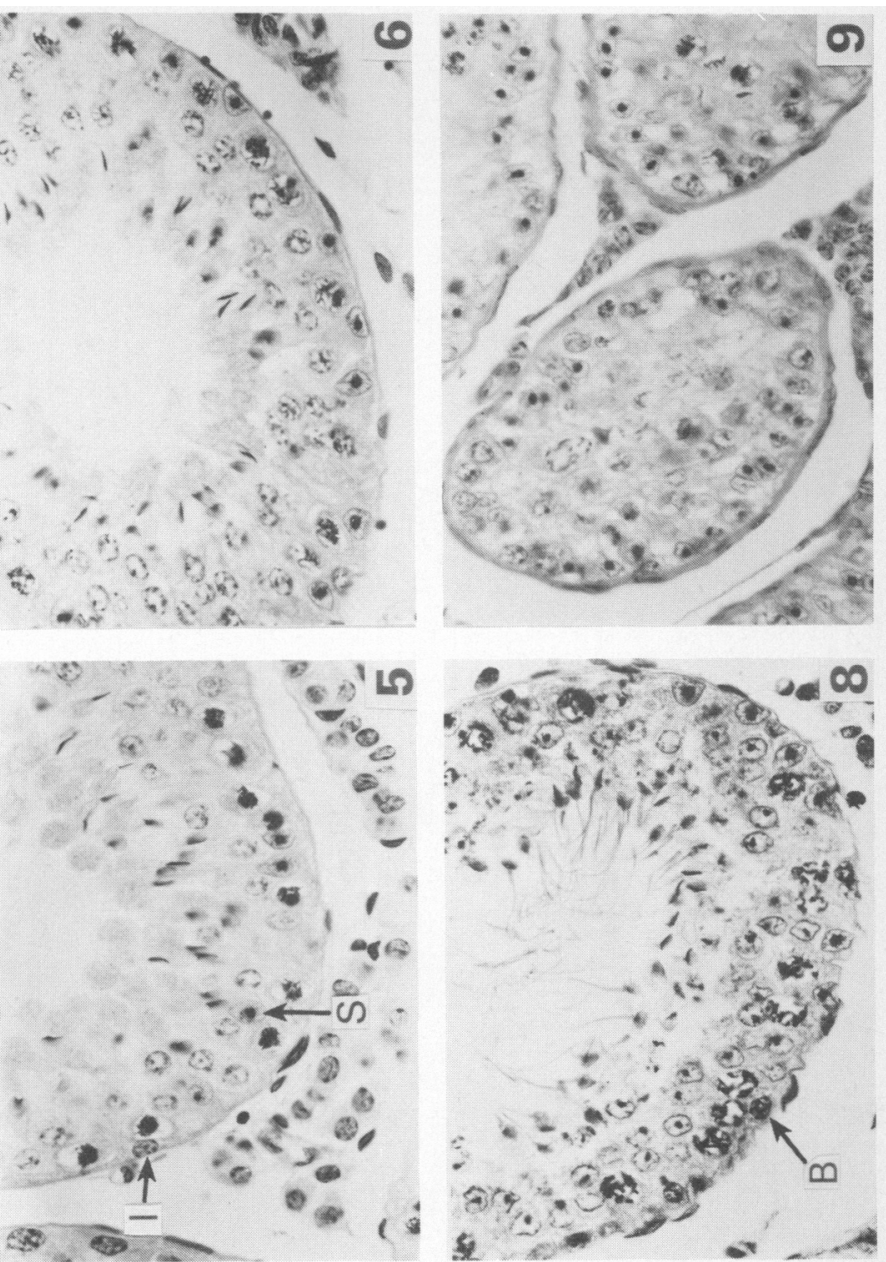

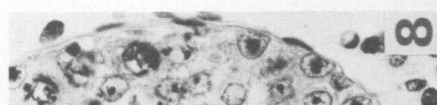
$\left.x 3^{6}+4^{2}, 83\right)^{2}$

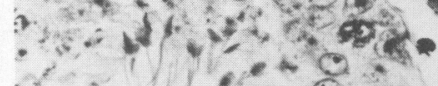
20

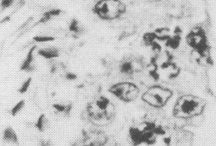
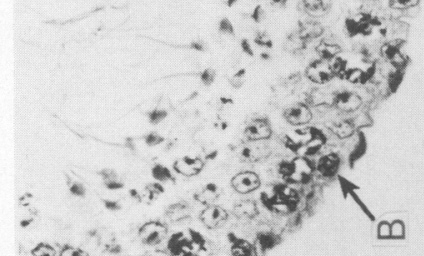

$87, \cdot 32,3$

$a^{2}=0$

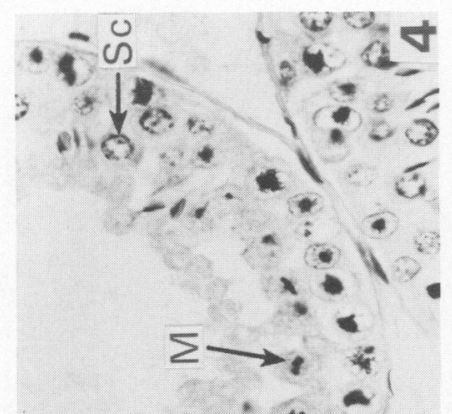

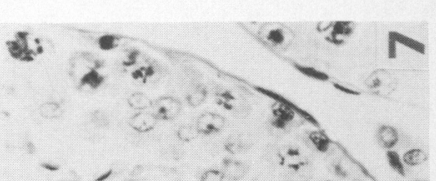

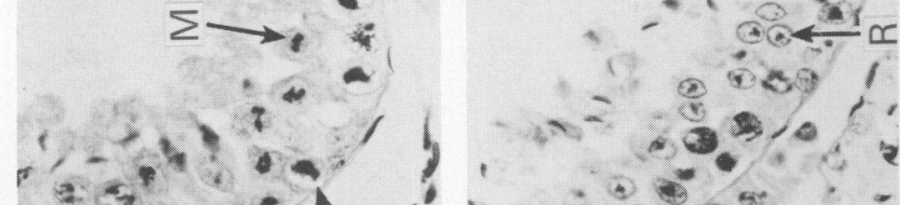

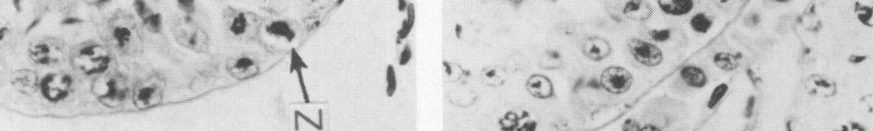
का $\infty$, 12 
rabbit (Swierstra \& Foote, 1963), dog (Foote, Swierstra \& Hunt, 1972), stallion (Swierstra, Gebauer \& Pickett, 1974) and vole (Grocock \& Clarke, 1975). It was not possible to distinguish Stages V and VI on the basis of the nuclear morphology of the round spermatids because in the grey squirrel, as in the dog (Foote et al., 1972), these changes were not clearly defined. Instead the development of primary spermatocytes from zygotene to early pachytene was used to distinguish Stages V and VI. Another characteristic feature of Stage V in the squirrel was the movement of the Sertoli cell nuclei away from the basement membrane and their close association with the bundles of developing spermatids. In other species such as the vole (Grocock \& Clarke, 1975) this close association of spermatids with Sertoli cells is achieved by movement of the spermatids. The duration of each spermatogenic stage is reflected in their frequencies; those of high frequency representing long stages in spermatogenesis, whilst those of low frequency represent short stages. Stage VIII is the most frequent and therefore the longest stage in the squirrel, as it is in the vole while Stage $V$ is the shortest stage in the squirrel, as it is in the ram and rabbit.

From the cell counts shown in Table 3 it appears that two intermediate spermatogonia are produced in Stage III from three type A spermatogonia. A possible explanation is that one of the type A spermatogonia remains dormant for long periods, as suggested in the scheme of spermatogenesis proposed for the bull (Courot, Hochereau-de Reviers \& Ortavant, 1970). The intermediate spermatogonia had doubled their number by Stage VI. It might have been expected that 8 type B spermatogonia would be produced in Stage VIII by division of 4 intermediates but only 5 were observed. The subsequent division to primary spermatocytes appears to proceed fairly efficiently, but there is a substantial cell loss during the maturation divisions. The division from primary to secondary spermatocytes could not be estimated with any accuracy because division to round spermatids proceeded immediately. The final yield of 27 spermatozoa, excluding those at Stage VIII, when some may have left the tubules, represents a total cell loss of $58 \%$. The low numbers of spermatozoa in the testes of the grey squirrel are partly the result of fewer spermatogonial divisions compared with those in most other mammals, as well as a low efficiency of spermatogenesis. This sparsity of spermatozoa lining the lumen of the seminiferous tubules in the grey squirrel was commented on by Pudney (1976) and is also a feature of the fox squirrel (Sciurus niger) (Kirkpatrick, 1955).

It was not possible to identify distinct stages of spermatogenesis in regressed testes. The numbers of type A spermatogonia and Sertoli cells were similar to those found in active testes whereas the numbers of intermediate and especially type B spermatogonia were reduced. The few recognizable primary spermatocytes appeared to be degenerating. Similar histological changes in regressed testes have been described by Pudney (1976) who examined 6 animals trapped between February and June and concluded that no regular testicular periodicity was exhibited by the grey squirrel. We have similarly trapped a few individual squirrels with regressed testes at various times during the breeding season. However, we have consistently trapped squirrels with regressed testes between July and the end of October. Of the 7 squirrels recorded during these months by Pudney (1976) none was classified as sexually active. We believe that when all the available data are examined, the evidence will confirm that most adult male squirrels are sexually quiescent in the autumn. The factors responsible for this regression are not known; daylength is probably not the primary environmental cue because the regression may occur before the summer solstice. In 1977/78 and 1979/80 the regression of the testes was prolonged until the following March, resulting in the absence of spring breeding in a localized population of grey squirrels. It is likely that a similar prolongation of the period of regression caused the absence of spring breeding reported by Dubock (1979b) for 1973. The factors responsible for maintaining the period of regression may be different from those which initiate it and the suggestion that food supply may be involved (Dubock, 1979b) seems reasonable. 
We thank the Forestry Commission for financial support and much help and advice with the trapping, care and maintenance of squirrels; Lorna Karpeta and Ivor Hughes for technical assistance; and Dr Anne Grocock for helpful discussions.

\section{References}

Allanson, M. (1933) The reproductive processes of certain mammals V. Changes in the reproductive organs of the male grey squirrel (Sciurus carolinensis). Phil. Trans. R. Soc. B 222, 79-96.

Brauer, A. \& Dusing, A. (1961) Sexual cycles and breeding seasons of the gray squirrel Sciurus carolinensis. Trans Kentucky Acad. Sci. 27, 16-27.

Brown, L.C. \& Yeager, L.E. (1945) Fox squirrels and gray squirrels in Illinois. Bull. Illinois Nat. Hist. Survey 23, 449-536.

Courot, M., Hochereau-de Reviers, M.T. \& Ortavant, R. (1970) Spermatogenesis. In The Testis, Vol. 1, pp. 339-432. Eds A. D. Johnson, W. R. Gomes \& N. L. VanDemark. Academic Press, New York.

Dubock, A.C. (1979a) Methods of age determination in grey squirrels (Sciurus carolinensis) in Britain. J. Zool., Lond. 188, 27-40.

Dubock, A.C. (1979b) Male grey squirrel (Sciurus carolinensis) reproductive cycles in Britain. J. Zool., Lond. 188, 41-51.

Foote, R.H., Swierstra, E.E. \& Hunt, W.L. (1972) Spermatogenesis in the dog. Anat. Rec. 173, 341-352.

Glauert, A.M. (1975) Fixation, Dehydration and Embedding of Biological Specimens. North Holland Publishing Company, Amsterdam.

Grocock, C.A. \& Clarke, J.R. (1975) Spermatogenesis in mature and regressed testes of the vole (Microtus agrestis). J. Reprod. Fert. 43, 461-470.

Kirkpatrick, C.M. (1955) The testis of the fox squirrel in relation to age and seasons. Am. J. Anat. 97, 229-255.

Kirkpatrick, C.M. \& Hoffman, R.A. (1960) Ages and reproductive cycles in a male gray squirrel population. J. Wildl. Mgmt 24, 219-221.

Nixon, C.M. \& McClain, M.W. (1975) Breeding seasons and fecundity of female grey squirrels in Ohio. J. Wildl. Mgmt 39, 426-438.

Ortavant, R. (1958) Le cycle spermatogenetique chez le belier. These, docteur es sciences, Université de Paris, France.

Ortavant, R., Courot, M. \& Hochereau, M.T. (1969) Spermatogenesis and morphology of the spermatozoon. In Reproduction in Domestic Animals, 2nd edn, pp. 251-276. Eds H. H. Cole \& P. T. Cupps. Academic Press, New York.

Pudney, J. (1976) Seasonal changes in the testis and epididymis of the American grey squirrel, Sciurus carolinensis. J. Zool., Lond. 179, 107-120.

Roosen-Runge, C.E. \& Giesel, L.O. (1950) Quantitative studies on spermatogenesis in the albino rat. $A m . J$. Anat. 87, 1-30.

Shorten, M. (1954) Squirrels. Collins, London.

Smith, N.B. \& Barkalow, F.S., Jr (1967) Precocious breeding in the gray squirrel. J. Mammal. 48, 328-330.

Swierstra, E.E. \& Foote, R.H. (1963) Cytology and kinetics of spermatogenesis in the rabbit. J. Reprod. Fert. 5, 309-332.

Swierstra, E.E., Gebauer, M.R. \& Pickett, B.W. (1974) Reproductive physiology of the stallion. I. Spermatogenesis and testis composition. J. Reprod. Fert. 40, 113-123.

Taylor, J.C. (1969) Social structure and behaviour in a grey squirrel population. Ph.D. thesis, University of London.

Received 11 June 1981 